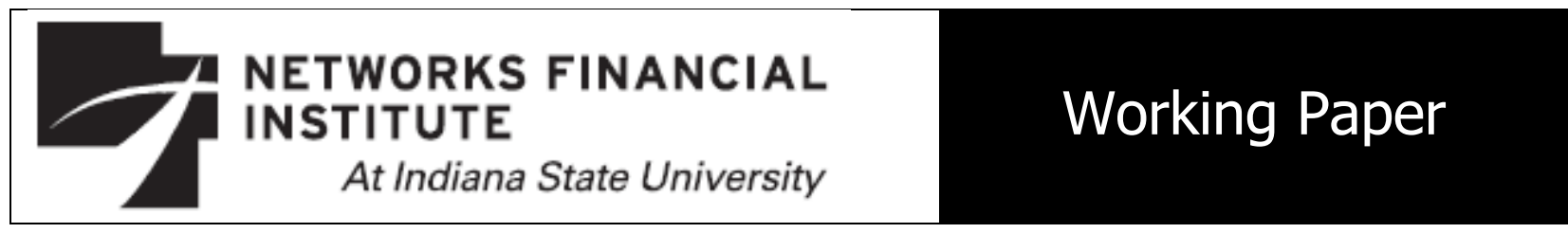

2012-WP-05

June 2012

\title{
Is Technology-Enhanced Credit Counseling as Effective as In-Person Delivery?
}

John M. Barron and Michael E. Staten

This paper was presented at NFI's May 14-15, 2009 conference in Indianapolis, IN entitled "Improving Financial Literacy and Reshaping Financial Behavior."

Abstract: This paper compares outcomes for borrowers who received face-to-face credit counseling with similarly situated consumers who opted for counseling via the telephone or internet. Counseling outcomes are measured using consumer credit report attributes one or more years following the original counseling. The primary analysis utilizes data from a sample of 26,000 consumers who received credit counseling either in-person or via the telephone during 2003. A second sample of 12,000 clients counseled in 2005 and 2006 was provided by one of the agencies to examine internet delivery. Technology-assisted delivery was found to generate outcomes no worse - and at some margins better than face-to-face delivery of counseling services.

About the Authors: Dr. Michael E. Staten holds the Take Charge America endowed chair in the Norton School of Family and Consumer Sciences at the University of Arizona. He is also director of the Take Charge America Institute for consumer financial education and research. Staten is recognized nationally as an expert on retail credit market policy issues and has testified often before Congress and various state legislatures. Over the past 20 years, he has designed and conducted research projects on a wide range of policy-oriented issues involving consumer and mortgage credit markets, initially as director of the Credit Research Center at Purdue University $(1988$ - 1997), and later as Distinguished Professor and Executive Director of the re-located Credit Research Center at Georgetown University (1997 - 2006), and the George Washington University School of Business (2006-2007). He has published numerous articles on retail financial services in academic journals and edited volumes. He has made invited presentations at workshops and events sponsored by the Federal Trade Commission, the Federal Deposit Insurance Corporation, the Federal Reserve Board, and Washington, DC think-tanks including the American Enterprise Institute and the Brookings Institution. Dr. Staten received his Ph.D. in economics from Purdue University's Krannert Graduate School of Management in 1980. Professor John M. Barron is Economics Department Head and Loeb Professor of Economics at Purdue University's Krannert School of Management. His primary teaching interests include the economics of information and macroeconomics. His current research interests are labor economics and contract theory. He has had a number of articles published, including papers in the American Economic Review, Journal of Human Resources, Journal of Law and Economics, International Economic Review, Review of Economics and Statistics, and the Journal of Labor Economics. He has also published five books. He earned a Ph.D. in Economics from Brown University.

This research was jointly sponsored by the Consumer Federation of America and American Express as part of a multi-year program to identify best practices in the credit counseling industry and quantify the impact of those practices on consumers. The views expressed are those of the individual author and do not necessarily reflect official positions of Networks Financial Institute. Please address questions regarding content to Michael E. Staten at statenm@email.arizona.edu. Any errors or omissions are the responsibility of the authors. NFI working papers and other publications are available on NFI's website (www.networksfinancialinstitute.org). Click "Thought Leadership" and then "Publications/Papers." 


\section{Is Technology-Enhanced Credit Counseling as Effective as In-Person Delivery? \\ John M. Barron and Michael E. Staten}

\section{INTRODUCTION}

This paper presents evidence on the comparative effectiveness of credit counseling delivery channels. As recently as the late 1990s, the conventional wisdom was that one-on-one counseling, conducted face-to-face, was the gold standard for effective delivery. Telephone counseling of borrowers - or other delivery channels that substituted technology for the face-toface experience - was considered a weaker substitute (Loonin and Plunkett, 2003). But, the growing demand from consumers for telephone delivery of credit counseling of all kinds has fueled an ongoing debate over the relative effectiveness of the delivery channel. The more recent introduction and popularity of internet delivery has intensified the discussion of whether technology can provide an effective substitute for the traditional face-to-face experience.

As a recent example, the credit counseling and debtor education required for bankruptcy petitioners under the Bankruptcy Abuse Prevention and Consumer Protection Act of 2005 was originally framed to be delivered in-person. Practical limits on nationwide availability of faceto-face bankruptcy counseling led the Executive Office for the U.S. Trustees (EOUST) to approve agencies to do telephone and eventually internet bankruptcy counseling. Consumers have clearly demonstrated an overwhelming preference for technology-assisted delivery of bankruptcy counseling (National Foundation for Credit Counseling, 2006). Even more recently, practical concerns about how to handle overwhelming demand have driven decisions to approve technology-assisted mortgage foreclosure counseling, as the tidal wave of past-due mortgages overtook the ability of face-to-face providers to meet the needs of distressed consumers. But, 
published evidence on the impact of these counseling delivery methods in any loan context is sparse.

Because in-person delivery is much more resource-intensive in requiring brick and mortar offices, evidence on the comparative effectiveness of technology-assisted delivery has important implications for public policy that would encourage widespread availability of counseling options for consumers throughout the country. A small body of empirical work has shown that credit counseling (Elliehausen, Lundquist and Staten, 2007) and pre-purchase homeownership counseling (Hirad and Zorn 2002; Hartarska and Gonzalez-Vega 2005) can help to reduce future repayment problems for debtors. At least one study has found that clients who stay on counseling agency-administered debt repayment plans for more than 18 months reported improved financial management behaviors and fewer stressful events (Kim, Garman, and Sorhaindo 2005). But, these and other prior studies of credit counseling effectiveness offer little insight as to which delivery method, if any, is associated with the largest benefit.

Collins (2007) examined the impact of counseling delivery method (telephone vs. faceto-face) on consumer outcomes in the context of mortgage foreclosure counseling. He found that consumer ratings of the value of counseling rose and foreclosure frequency fell, the greater the time spent in counseling, but he found no clear impact of delivery channel.

Collectively, the existing studies suggest that counseling can help borrowers physically, emotionally and economically, and that a longer exposure to counseling is associated with greater benefits. The following sections extend this research to examine the impact of the counseling delivery channel across two large samples of credit counseling clients who received budget/financial counseling (bankruptcy and mortgage foreclosure counseling sessions are excluded from the analysis). Many of the consumers in the study subsequently enrolled in 
agency-administered Debt Management Plan (DMP) to manage repayment of their unsecured debts, but the large majority of consumers in the samples receive financial counseling only (no DMP), and in some cases recommendations for legal and other assistance. Effectiveness of counseling is gauged by using credit bureau data to examine the credit profile of counseled clients at the time of the initial counseling session and at distinct points one or more years after counseling.

\section{TECHNOLOGY-ASSISTED CREDIT COUNSELING}

The credit counseling industry as we know it today was developed in the mid-late 1960s (Staten 2006). In the early days of the industry, consumers who needed counseling assistance traveled by automobile or bus to a local agency office to meet face-to-face with a counselor and discuss their financial difficulties. Over the next 4 decades, the demands on consumers' time and the complexity of their lives steadily increased. Existing agencies and new entrants adapted their service models and expanded delivery options to remain available and relevant to consumers and better meet their schedules, learning styles and preferences.

The first step (late 1960s through early 1990s) was the brick-and-mortar expansion of agency offices and branch locations to support a broader geographic reach of face-to face counseling availability. New entrants to the industry in the early 1990s introduced telephone counseling in order to rapidly expand capacity without major investments in brick and mortar offices. Consumer preferences for the convenience of telephone delivery spurred existing agencies to make similar investments in technology. By the end of the decade, most of the larger counseling agencies in the country offered telephone counseling as either an option to face-toface delivery or as their only delivery mechanism. 
Telephone counseling made access to counseling services more convenient and served to safely expand service hours beyond traditional business hours, in some cases to 24 hours a day/7 days a week. Later, internet counseling also catered to consumer preferences for 24/7 availability, but offered a greater degree of anonymity for consumers and certain cost-saving efficiencies for agencies. Each service delivery method - face-to-face, telephone and internet has its own relative strengths and weaknesses. Table 1 details the advantages of the different delivery channels in helping clients with particular preferences or needs.

\section{DATA AND METHODOLOGY}

In response to a national request for proposals distributed by the Consumer Federation of America to over 600 credit counseling agencies in August 2004, 34 agencies submitted grant proposals to participate in a multi-year study of credit counseling effectiveness. A review committee consisting of representatives from American Express, Consumer Federation of America and Georgetown University evaluated the proposals and selected ten finalists to participate in an empirical study of the effect of credit counseling on long-term borrower behavior. Finalists were those agencies that received high ratings in the subjective areas of evaluation (e.g., data capture ability; description of the quality of their programs; evidence of innovative programs). Site visits were conducted for each of the agency finalists, and included opportunities to listen to ongoing counseling sessions and intake calls, either "live" or prerecorded in conjunction with each agency's quality assurance program. Among the resulting group of ten agencies, some did telephone counseling exclusively, some specialized in face-toface counseling, and a few offered internet delivery. By selection, all of the agency finalists demonstrated an emphasis on client education and identification of the cause of underlying financial problems. ${ }^{1}$ 
An initial objective of the study was to utilize the experience of agencies that appear to be high-quality providers in order to see if, when done well, counseling effectiveness is influenced by delivery method. Each agency was asked to provide data for all consumers who received their first budget/financial counseling session during March and April of 2003. As a matter of practice, all of the agencies in the sample conducted initial client interviews lasting anywhere from 30 to 75 minutes. The interview collected detailed budget information as well as an inventory of assets and debts. Counselors also identified potential causes of the clients' financial problems. Options were discussed. The counselor's recommendation and a written action plan were part of the product delivered to the consumer. One option that was offered to many clients was enrollment in an agency-administered debt repayment program called a Debt Management Plan (DMP). Consumers recommended for a DMP could choose not to enroll, but the DMP recommendation is a signal that the counselor thought that customer was qualified.

For this study, credit bureau information was used to construct several outcome measures of counseling effectiveness. Counseling has at least two objectives. Since clients almost always seek counseling assistance because they sense that they are in financial trouble, a primary goal is to provide advice and assistance to relieve the immediate problem and to lower the burden of debt. But, a second and longer-term goal is to improve borrower awareness, planning, and budgeting skills to prevent overextension in the future. Decision-assistance "triage" and education are intertwined in a good counseling session. An evaluation of progress toward both goals requires some objective measures of credit usage and payment performance over an extended period following counseling. Credit report information provides such a measure.

For this project one of the three major U.S. credit reporting agencies, Trans Union, LLC (TU), matched the client data provided by the counseling agencies from the counseling sessions 
in March-April 2003 to credit report data on each client drawn from the second quarters of 2002, 2003, 2005 and 2007. This produced for each counseled client a credit bureau snapshot one year prior to counseling, at the time of counseling, and at points two and four years after the initial counseling.

The credit bureau provided a number of credit-usage attributes for each individual. Of particular interest were two types of credit scores. Both scoring products are risk management tools that TU markets to creditors and other firms making credit-related decisions, including accept/reject, pricing and credit line authorization decisions. One product reflects the risk of a serious delinquency on any account (equivalent in concept and roughly equivalent in scaling to the widely-known FICO score product developed by Fair Isaac, Co.), while the second reflects the risk of bankruptcy.

The matching process yielded 59,950 clients for whom a complete set of credit reports and credit risk scores was available through $2005 .^{2}$ Each agency sent their files directly to TU; TU then matched based on available personal identifiers and sent the matched data, stripped of all unique personal identifiers, to the authors.

Of the 59,950 clients in the sample, 40,592 were counseled in 2003 by telephone (67.7\%), 13,567 were counseled in-person (22.6\%) and the remaining 5,791 clients were counseled via the internet $(9.7 \%)$. Five of the ten participating agencies offered all three delivery channels to consumers. Three agencies were primarily or exclusively telephone counseling operations, and two agencies offered face-to-face counseling almost exclusively. It is important to remember that the sample is not a representative sample of all counseling clients industrywide. Consequently, the particular mix of delivery channels in the sample is greatly influenced by the business models of the participating agencies. 
Table 2 reports differences across the agencies in the recommendations that arose from the counseling session. Note that some agencies (e.g., Agency E and Agency J) did not capture much detail about the outcome of the counseling session, other than whether a DMP was offered. The table displays large differences in the extent to which counseling resulted in a debt management plan being proposed. However, the far right-hand column in Table 2 shows that when one considers the percent of clients who actually started a DMP, the differences across agencies are much smaller, though still significant.

Table 3 reports the recommendation of the counselor by type of delivery channel, as well as the percent of clients in each delivery channel who actually agreed to and started payments on a DMP. Note that as a percent of all counseling sessions, DMP recommendations were made least frequently for face-to-face counseling clients. Nevertheless, face-to-face sessions display the highest "conversion rate" in terms of percent of clients who start a DMP.

\section{COUNSELING DELIVERY METHODS AND OUTCOMES}

This section provides various tests of the effect of delivery channel on the clients' credit profile examined several years after counseling. Because internet counseling was not consistently defined across agencies in 2003 (e.g., some offered online intake of client financial information but did not classify that as Internet counseling; others offered some form of interactive chat or telephone call-back following online input of information) we limit the following analysis to individuals who had an initial counseling session either over the phone or in person. In addition, the sample was restricted to individuals who had no record of a bankruptcy filing in their credit report at the time of counseling. In a subsequent section we return to an evaluation of internet counseling using data from a single agency. 


\section{Predictors of Choice of Delivery Channel}

Counseling delivery is greatly driven by consumer preferences. Since counseling is voluntary and is offered in a competitive market environment, consumers generally choose the delivery option. Because some agencies specialize in a specific delivery channel and others offer a range of delivery methods, most consumers have a meaningful choice of delivery options because they have two or more counseling agencies from which to choose. But, the choice of delivery channel could influence the observed outcomes in the years following counseling for reasons other than the effectiveness of the delivered counseling. If consumers who pick telephone delivery have different attitudes, motivation and prior credit usage or risk profiles than consumers who pick in-person delivery, their post-counseling credit experience may look quite different.

While data on client attitudes is not available in this sample, the credit report data provides an opportunity to account for client risk profile at the time of counseling. This section examines whether such observable variables are associated with counseled clients' choice of delivery channel. For this analysis the sample was restricted to consider only 25,997 clients of the five agencies that provided reasonably large samples of individuals counseled both by telephone and in person. ${ }^{3}$ For these clients, their counseling agency offered a choice of delivery channels. Agency brand name, educational philosophy and content would be the same regardless of the delivery channel choice made by the consumer.

Table 4 reports the results of a Probit analysis for clients of these five agencies. The probit model is specified to predict the probability that a client picks face-to-face delivery (with telephone delivery as the alternative). The table displays two columns of estimated coefficients: 
the first includes only variables from the credit report and the second column includes credit report variables plus three additional variables derived from the counseling interview, including counselor experience (in months). The estimated coefficients on the independent variables indicate that individuals with the highest delinquency scores (i.e., lowest risk) are less likely to seek face-to-face counseling. With regard to other credit bureau variables, individuals with more accounts with positive balances and larger mortgage balances are more likely to choose face-toface counseling, other things equal. Conversely, consumers with more bank cards and more unsecured debt tend to seek telephone counseling. Finally, counselors doing face-to-face delivery in this sample tended to be more experienced.

An Analysis of Telephone Delivery vs. In-Person delivery: Methods and Outcomes The impact of delivery channel was determined for three distinct client credit outcomes: bankruptcy incidence, and two general measures of creditworthiness in the form of a delinquency risk score and a bankruptcy risk score. The set of three outcomes is measured at two points in time - two years following the counseling (March, 2005) and four years following the counseling (March, 2007).

Probit or Ordinary Least Squares (OLS) models were estimated for the three credit outcomes, again using the subset of the full sample that included only clients from the five agencies that offered a choice of delivery channel. While the results of the restricted sample estimates are reported below, the same analysis conducted on the full sample of ten agencies yielded substantially similar results.

Table 5 displays the results of Probit and OLS models for the sample of 25,997 consumers. The first three columns display estimated coefficients for each of the credit outcomes measured four years after counseling. The three columns furthest to the right display 
the coefficients for the credit outcomes measured only two years after counseling. Both are displayed in the table because reforms to the federal bankruptcy law in 2005 dramatically affected bankruptcy filing incentives and filing volumes and this may have affected our credit outcome measures by 2007. However, the results from the estimates derived two years after counseling are substantially similar to those at a point four years after counseling.

The estimated models include explanatory variables that capture more than a dozen items from the client's credit report at the time of counseling in 2003 (including risk scores). Also included are variables that reflect information gathered during the counseling interview, including delivery channel, counselor experience and the counselor's recommendation, and whether a DMP was recommended and started.

Many of the variables are significant in the expected direction. For example, a higher client bankruptcy risk score in 2003 is associated with lower bankruptcy incidence during the years following counseling, as well as higher (better) risk scores both two and four years into the post-counseling period, other things equal. The number of revolving credit accounts (labeled "non-installment" in Table 5) with utilization rates greater than 50\% (i.e., balances greater than $50 \%$ of account credit limit) is positively associated with bankruptcy incidence and leads to lower credit scores in the years following counseling. A larger number of credit inquiries in the past 6 months (a sign of repeated applications for credit) yields a similar result. A larger number of accounts delinquent at the time of counseling increases the incidence of bankruptcy and reduces the level of the clients risk scores two and four years later.

Additional information on the financial situation of the consumer seeking counseling is likely imbedded in the counselor's outcome recommendation. Insights gained through the counseling interview presumably convey at least some of the client's private information about 
financial circumstances that is not otherwise observable through credit report data. Presumably, that information would influence the counselor's recommended plan of action.

To see if such information is important, Table 5 includes "evaluation" variables that indicate the recommendation of the counselor. The counselor can recommend a DMP, refer the client to other agencies for legal or other assistance, or suggest that the individual can selfmanage the situation. We also include two additional variables indicating whether a DMP was actually started. One variable identifies cases where a DMP was recommended and started, and the second variable identified cases in which a DMP was not recommended, but was started anyway (perhaps as a result of a subsequent change in the client's situation).

The counselor's recommendation does indeed convey information not otherwise observable through the credit report variables. Perhaps not surprisingly, individuals who are considered capable of self-management fare best in terms of a significantly lower incidence of a bankruptcy filing and higher risk scores (both bankruptcy and delinquency risk scores) in both 2005 and 2007. At the other end of the spectrum, clients who are referred for legal assistance (e.g., bankruptcy) have the highest incidence of bankruptcy within the next two years, and experience significantly lower risk scores two years later, compared to the rest of the sample. Interestingly, clients for whom the counselor recommends a DMP, and who actually start payments on a plan, have a significantly lower incidence of bankruptcy and higher risk scores both two and four years later.

As for the impact of the counseling delivery channel, note that among individuals who otherwise appear identical in terms of credit bureau variables (i.e., controlling for credit bureau characteristics) and counselor recommendations, face-to-face clients have no statistically significant difference in delinquency risk scores four years after counseling, as compared to 
telephone counseling clients. In terms of bankruptcy incidence and subsequent bankruptcy risk, in-person clients fare worse than those who received telephone counseling (significantly higher bankruptcy incidence and lower bankruptcy risk score). ${ }^{4}$

\section{INTERNET VS TELEPHONE VS FACE-TO-FACE DELIVERY}

One agency in the sample began internet counseling as far back as 1999 and has made substantial investments in refining the channel since. Consumer Credit Counseling Service of Greater Atlanta maintains that effective counseling through any channel requires consumer engagement and interaction with a certified counselor. The agency has incorporated this interaction into their Internet counseling model with a two-step process - mandatory Live Chat with a counselor throughout the online session and a secondary offline review by another counselor at the end of the process to ensure the initial recommendations and options address the client's issues.

Counseling via the Internet offers several benefits over telephone and face-to-face counseling that help to overcome consumer reluctance to participate in counseling. Discussions with counselors at CCCS-Atlanta revealed the following advantages to internet counseling access:

Convenience: Consumers can access help from any location and at any time of the day, avoiding travel time and costs. But, unique to internet counseling, clients can start and stop their sessions as needed, and can always begin their counseling session immediately.

Organization: The stress of a financial crisis often results in poor recordkeeping and/or limited awareness of many important financial details. CCCS-Atlanta found that in face-to-face meetings, clients often lacked the necessary information to complete their counseling session, 
which required them to follow-up with their counselor at a later time. Online, clients can take as much time as they need to collect any required information.

Anonymity: For consumers who may be hesitant to face another person or even to talk over the phone about their financial distress, the Internet offers them a greater degree of anonymity. Learning Style: For visual learners, the agency's website and online counseling process is userfriendly and offers the ability to see, read and think about questions and move forward at the client's own pace. Help and support is readily available through a Live Chat with a counselor who helps the client complete the session.

To support an analysis of both telephone and internet delivery, relative to in-person delivery, CCCS-Atlanta provided a supplemental sample of the 7,500 clients who received budget/financial counseling during March and April of 2005 and an additional 6,700 clients who received budget/financial counseling during March and April of 2006. For this phase of the analysis, Equifax , Inc., another one of the three major U.S. credit reporting agencies, matched the client data provided by the counseling agency to credit report data on each client at the time of counseling, one year prior to counseling and one year following counseling. Each credit report snapshot contained a number of credit-usage attributes for each individual, as well as two types of credit scores. Both scoring products are risk management tools that Equifax markets to creditors and other commercial customers that make credit-related decisions. One product reflects the risk of a serious delinquency on any account (equivalent in concept and roughly equivalent in scaling to the widely-known FICO score product developed by Fair Isaac, Co.), while the second reflects the risk of bankruptcy.

The matching process yielded approximately 7,000 clients counseled in 2005 and 6,000 clients counseled in 2006 for whom a complete set of credit reports and credit risk scores were 
available for each of the three years. Equifax sent the matched data, stripped of all unique personal identifiers, to the authors.

Table 6 provides average risk score statistics for budget counseling clients who were counseled during either 2005 or 2006 . The table reports mean risk score levels one year prior to counseling, at the time of counseling and one year following counseling, as well as changes in those scores. As expected, the average client score falls during the year prior to counseling and increases in the year following counseling. With respect to both risk and bankruptcy scores, Table 6 also indicates that in both 2005 and 2006, the average internet client had a higher risk score one year prior to counseling, relative to clients in other channels. In addition, internet clients experienced the largest reduction in their risk score during the prior year, relative to other clients.

Of course, the above discussion is based solely on observing the average scores across delivery channels. Such average scores do not account for the possibility that, at the time of counseling, clients may differ in the potential for counseling to improve their credit scores, and that this characteristic may not be randomly distributed in clients across delivery channels. Table 7 identifies demographic differences across clients by delivery channel. For example, individuals who choose internet counseling tend to be younger, have much higher monthly income, and report substantially greater holdings of both assets and unsecured debt, relative to clients counseled through the other two channels.

Next, the analysis used regression analysis to examine the relationship between delivery channel and subsequent risk scores. However, because 2005 was a year during which major changes to the federal bankruptcy laws were passed and enacted (changes that substantially altered incentives to file for personal bankruptcy or seek traditional credit counseling), the 
following discussion will address only those clients who received budget/financial counseling during 2006. Table 8 reports regression results that describe the impact of delivery channel on client delinquency risk scores, measured in the second quarter of 2007, about one year after the counseling experience. Table 9 reports similar estimates of the impact of delivery channel on bankruptcy risk scores, also measured one year after counseling.

In both tables, various regression model specifications allow for circumstances other than delivery channel to influence risk score changes. For example, in examining the factors that determine changes in scores during the year leading up to the counseling (column $\mathrm{A}$ in each table), the model utilizes several variables in addition to the delivery channel, including variables that identify home ownership, age, marital status, reported assets holdings, reported level of unsecured debt, reported net income, the client's credit score at the time of counseling, and the counselor's assessment of the client's financial condition as evidenced by the counselor's recommended action step. To account for a potential non-linear relationship between the initial risk score and subsequent change in risk score, the model includes both the initial score and the squared value of the initial score.

For the regression models that examine the change in the risk scores in the year following counseling, the tables report several specifications that vary in the types of variables used to account for client characteristics. The simplest specification includes only the delivery channel (column B); the second specification adds variables indicating the counselor's recommendation (column C); the third specification includes various demographic variables (column D); the fourth specification includes all preceding variables plus the client's risk score at the time of the last counseling appointment, both its level and its squared value (column E); the final specification include all of the preceding plus the change in the level of the risk score over the 
year prior to the last counseling appointment (column F). Note that the excluded delivery channel is face-to-face delivery (i.e., the coefficients on the variables for internet and telephone counseling indicate change in the dependent variable relative to face-to-face delivery). The results indicate that, compared to face-to-face delivery, there is no statistically significant effect of either the internet or the telephone delivery channel on subsequent changes in a client's risk score measured 12 months after counseling, other things equal. The same result was found for the impact of delivery channel on bankruptcy risks cores (Table 9).

\section{CONCLUSIONS}

Across several large samples of credit counseling clients, the analysis described above could find no evidence that technology-assisted counseling was associated with subsequent client credit profiles worse than those for consumers who received face-to-face counseling. If we take post-counseling client creditworthiness - as measured by commercially available risk scoring products one or more years after the counseling - as an indicator of whether a credit counseling experience was helpful to a consumer, then the evidence suggests that both telephone and internet counseling can be just as effective as face-to-face counseling.

Several caveats to these findings should be noted. First and foremost, because the sample of participating agencies was not selected to be representative of industry-wide practices, the results cannot necessarily be considered representative of the typical experience of counseled consumers nationwide. Instead, they reflect what is obtainable from a group of agencies that emphasize client education and identification of the underlying cause of financial problems. The fact that telephone counseling generated outcomes no worse - and at some margins better - than 
face-to-face delivery of counseling services suggests that, when done well, the two delivery channels can be equally effective.

The impact of delivery channel was determined on three separate indicators of postcounseling outcomes for consumers, measured up to four years after the initial counseling visit. Two of these indicators (a commercially available bankruptcy risk score product; a commercially available new account delinquency risk score product) represent general measures of creditworthiness. In addition, the model examines the actual incidence of bankruptcy among the sampled clients during the four year period following counseling. While these indicators offer objective evidence on the consumer's credit experience from a variety of angles, they aren't the only possible indicators of counseling effectiveness. For example, survey evidence on consumers' perceived financial stress and confidence in their financial situation, pre and postcounseling, would augment the objective measures of consumer credit performance and provide a more complete picture of counseling's impact.

Finally, the results on the role of Debt Management Plans are particularly intriguing, but self-selection may be partly responsible. Clients who start DMPs outperform all other counseling clients on all of our outcome measures. Admittedly, clients who were recommended for DMPs are in better financial shape than clients who do not qualify. But, the evidence also indicates that between two borrowers who are recommended for a DMP (i.e., borrowers for whom a DMP is both a workable option and the best option), the borrower who actually starts payments in a DMP fares significantly better on all outcome measures at two-year and four-year milestones after counseling. Perhaps there is some residual self-selection effect driving this result (e.g., borrowers who make a commitment to start a DMP are more motivated to repay than borrowers that do not - although both sets of borrowers were sufficiently motivated to take the 
step of seeking counseling in the first place). Alternatively, perhaps the DMP experience itself (e.g., budgeting to make regular DMP payments; continued interaction with and reinforcement from the counseling agency) generates the improvement in the outcome indicators. In other words, there may be "education" value in the DMP experience, a question that has been hotly debated between the counseling industry and the U.S. Internal Revenue Service (which grants tax-exemption for educational institutions) and various regulatory agencies in recent years. Given the significantly improved credit profiles for clients who do start DMPs, this phenomenon deserves closer study. 


\section{References}

Collins, J.M. (2007). Exploring the Design of Financial Counseling for Mortgage Borrowers in Default. Journal of Family and Economic Issues, 28, 207-226.

Elliehausen, G., Lundquist, C., \& Staten, M. (2007). The Impact of Credit Counseling on Subsequent Borrower Behavior. Journal of Consumer Affairs, 41, 1-28.

Hartarska, V., \& Gonzalez-Vega, C. (2005). Credit Counseling and Mortgage Termination by Low-Income Households. Journal of Real Estate Finance and Economics, 30, 227-243.

Hirad, A., \& Zorn, P. M. (2002). Pre-Purchase Homeownership Counseling: A Little Knowledge is a Good Thing. In Low-Income Homeownership: Examining the Unexamined Goal, Retsinas \& Belsky, eds. Washington, D.C.: The Brookings Institution Press. 146-174.

Kim, J., Garman, E. T., and Sorhaindo, B. (2005). Study Finds Positive Financial Behaviors Increased: Credit Counseling, Debt Management Effective. Journal of Family and Consumer Sciences, 97, 35-39.

Loonin, D. and Plunkett, T. (2003). Credit Counseling in Crisis: The Impact on Consumers of Funding Cuts, Higher Fees and Aggressive New Market Entrants. Washington, D.C., National Consumer Law Center and Consumer Federation of America.

National Foundation for Credit Counseling (2006). Consumer Counseling and Education Under BAPCPA: The Bankruptcy Abuse Prevention and Consumer Protection Act of 2005, Year One Report. Silver Spring, MD. 


\section{ENDNOTES}

${ }^{1}$ The ten agencies that emerged from this process as participants in the study were Auriton Solutions (Roseville, MN), ClearPoint Financial Solutions, Inc. (Richmond, VA), Consumer Credit Counseling Service of Greater Atlanta, Inc. (Atlanta, GA), Consumer Credit Counseling Service of Los Angeles (Los Angeles, CA), Consumer Credit Counseling Service of Montana (Great Falls, MN), Consumer Credit Counseling Service of North Central Texas (McKinney, TX), InCharge Debt Solutions (Orlando, FL), LSS Financial Counseling Service (Duluth, MN), Novadebt (Freehold, NJ), and Money Management International (Houston, TX).

${ }^{1}$ Subsequent matching of the sample to the 2007 credit bureau archive reduced the sample to 51,739 due to missing credit reports or credit scores for some individuals.

${ }^{1}$ In Table 1, these were agencies A, C, D, G, and H.

${ }^{1}$ Additional specifications that also included geographic controls (namely, variables indicating the state of residence of the individual) did not alter these findings. 
Table 1: Challenges for Consumers Seeking Counseling

\begin{tabular}{|c|c|c|c|c|}
\hline \multirow[t]{2}{*}{ Challenge } & \multirow[t]{2}{*}{ General Requirement } & \multicolumn{3}{|c|}{ Delivery Method } \\
\hline & & Face-to-Face & Telephone & $W e b$ \\
\hline $\begin{array}{l}\text { Time Required } \\
\text { To Complete } \\
\text { Counseling } \\
\text { Session }\end{array}$ & $\begin{array}{l}\text { The average } \\
\text { counseling } \\
\text { session takes } 60 \\
\text { minutes to } \\
\text { complete. }\end{array}$ & $\begin{array}{l}\text { Session takes the } \\
\text { average time for } \\
\text { counseling. Also } \\
\text { requires extra time to } \\
\text { travel to and from the } \\
\text { counseling office. }\end{array}$ & $\begin{array}{l}\text { Session takes the } \\
\text { average time for } \\
\text { counseling, but no } \\
\text { extra time for travel. }\end{array}$ & $\begin{array}{l}\text { Session takes the } \\
\text { average time for } \\
\text { counseling, but no } \\
\text { extra time for travel. } \\
\text { Added flexibility that } \\
\text { the client can stop and } \\
\text { restart the session at } \\
\text { their convenience. }\end{array}$ \\
\hline $\begin{array}{l}\text { Hours } \\
\text { Available for } \\
\text { Counseling }\end{array}$ & $\begin{array}{l}\text { The client must } \\
\text { fit the counseling } \\
\text { session into the } \\
\text { service } \\
\text { provider's } \\
\text { operating hours. }\end{array}$ & $\begin{array}{c}\text { Available during } \\
\text { standard business } \\
\text { hours, Monday to } \\
\text { Friday, } 8 \text { AM to } 5 \text { PM. } \\
\text { Little extended hour } \\
\text { a vailability. Limited } \\
\text { capacity at locations. }\end{array}$ & $\begin{array}{l}\text { Available } 24 \text { hours a } \\
\text { day, } 7 \text { days a week. } \\
\text { Additional capacity at } \\
\text { any time of day. }\end{array}$ & $\begin{array}{l}\text { Available } 24 \text { hours a } \\
\text { day, } 7 \text { days a week. } \\
\text { Additional capacity at } \\
\text { any time of day. }\end{array}$ \\
\hline Location & $\begin{array}{l}\text { The client must } \\
\text { find a way to } \\
\text { access service. }\end{array}$ & $\begin{array}{l}\text { Locations evenly } \\
\text { distributed across } \\
\text { geographic footprint, } \\
\text { but no offices outside } \\
\text { that area. }\end{array}$ & $\begin{array}{l}\text { Requires access to a } \\
\text { telephone, which can } \\
\text { be located anywhere. }\end{array}$ & $\begin{array}{l}\text { Requires access to a } \\
\text { computer, which can } \\
\text { be located anywhere, } \\
\text { and the Internet. }\end{array}$ \\
\hline $\begin{array}{c}\text { Learning } \\
\text { Style }\end{array}$ & $\begin{array}{l}\text { Each client } \\
\text { processes } \\
\text { information } \\
\text { according to } \\
\text { their learning } \\
\text { style. }\end{array}$ & $\begin{array}{l}\text { Offers the fullest way } \\
\text { for consumers to } \\
\text { interact, using both } \\
\text { visual, verbal and } \\
\text { non-verbal } \\
\text { communication. }\end{array}$ & $\begin{array}{l}\text { Requires good verbal } \\
\text { and listening } \\
\text { communication skills. } \\
\text { No ability for nonverbal } \\
\text { communication } \\
\text { during session. }\end{array}$ & $\begin{array}{l}\text { Predominantly visual } \\
\text { learning and reading, } \\
\text { plus written } \\
\text { communication via } \\
\text { Live Chat. }\end{array}$ \\
\hline $\begin{array}{c}\text { Emotional } \\
\text { Issues }\end{array}$ & $\begin{array}{l}\text { The client must } \\
\text { deal with a wide } \\
\text { array of emotions - } \\
\text { shame, guilt, } \\
\text { shock, } \\
\text { embarrassment - } \\
\text { before seeking } \\
\text { help. }\end{array}$ & $\begin{array}{l}\text { Requires client to face } \\
\text { the counselor in person, } \\
\text { an emotionally } \\
\text { challenging and } \\
\text { difficult format. } \\
\text { Offers the opportunity } \\
\text { for personal support } \\
\text { and affirmation by the } \\
\text { counselor. }\end{array}$ & $\begin{array}{c}\text { Offers more } \\
\text { anonymity and privacy } \\
\text { than face-to-face } \\
\text { counseling, but } \\
\text { still requires the client } \\
\text { to verbalize their } \\
\text { situation. }\end{array}$ & $\begin{array}{l}\text { Provides the most } \\
\text { anonymous and } \\
\text { private process, with } \\
\text { the client controlling } \\
\text { the interaction. }\end{array}$ \\
\hline Organization & $\begin{array}{l}\text { The client must } \\
\text { have a basic } \\
\text { level of } \\
\text { preparedness and } \\
\text { organization to } \\
\text { receive } \\
\text { counseling. }\end{array}$ & $\begin{array}{l}\text { Client needs to be } \\
\text { well organized and } \\
\text { bring all required } \\
\text { information and } \\
\text { paperwork to the } \\
\text { counseling session. }\end{array}$ & $\begin{array}{l}\text { Slightly more flexible, } \\
\text { as the client has the } \\
\text { ability to search for } \\
\text { and provide missing } \\
\text { information if they are } \\
\text { calling from home. }\end{array}$ & $\begin{array}{c}\text { Clients enter } \\
\text { information into } \\
\text { the system and can } \\
\text { stop/restart at their } \\
\text { convenience, allowing } \\
\text { them the ability to get } \\
\text { documents or } \\
\text { information as needed. }\end{array}$ \\
\hline
\end{tabular}


Table 2: Counselor Recommendations Across Agencies and Percent of DMPs Started

\begin{tabular}{|c|c|c|c|c|c|c|c|}
\hline & $\begin{array}{c}\text { Self Manage/ } \\
\text { Client Can } \\
\text { Handle }\end{array}$ & $\begin{array}{c}\text { DMP } \\
\text { recommended }\end{array}$ & $\begin{array}{c}\text { Financial } \\
\text { Counseling Only }\end{array}$ & $\begin{array}{c}\text { Referral to Other } \\
\text { Agency/ Service }\end{array}$ & $\begin{array}{c}\text { Referral to Legal } \\
\text { Assistance }\end{array}$ & Not Available & $\begin{array}{c}\text { Some DMP } \\
\text { payments made }\end{array}$ \\
\hline \multicolumn{8}{|l|}{ Agency } \\
\hline $\boldsymbol{A}$ & $3.70 \%$ & $26.70 \%$ & $64.80 \%$ & $0.60 \%$ & $4.20 \%$ & $0.00 \%$ & $16.90 \%$ \\
\hline $\boldsymbol{B}$ & $10.30 \%$ & $59.60 \%$ & $12.60 \%$ & $2.20 \%$ & $4.30 \%$ & $11.10 \%$ & $20.20 \%$ \\
\hline$C$ & $14.20 \%$ & $29.80 \%$ & $41.40 \%$ & $6.80 \%$ & $5.60 \%$ & $2.20 \%$ & $31.10 \%$ \\
\hline$D$ & $3.90 \%$ & $51.70 \%$ & $22.20 \%$ & $15.60 \%$ & $4.00 \%$ & $2.70 \%$ & $35.90 \%$ \\
\hline$E$ & $5.30 \%$ & $64.40 \%$ & $0.00 \%$ & $30.10 \%$ & $0.00 \%$ & $0.20 \%$ & $36.30 \%$ \\
\hline $\boldsymbol{F}$ & $4.50 \%$ & $43.20 \%$ & $26.10 \%$ & $6.90 \%$ & $7.80 \%$ & $11.50 \%$ & $25.00 \%$ \\
\hline$G$ & $5.20 \%$ & $77.10 \%$ & $1.10 \%$ & $7.80 \%$ & $4.80 \%$ & $3.90 \%$ & $27.40 \%$ \\
\hline $\boldsymbol{H}$ & $1.50 \%$ & $32.80 \%$ & $61.30 \%$ & $0.00 \%$ & $1.10 \%$ & $3.30 \%$ & $39.10 \%$ \\
\hline$I$ & $0.00 \%$ & $16.90 \%$ & $83.10 \%$ & $0.00 \%$ & $0.00 \%$ & $0.00 \%$ & $16.90 \%$ \\
\hline$J$ & $0.00 \%$ & $34.40 \%$ & $0.20 \%$ & $0.00 \%$ & $0.00 \%$ & $65.50 \%$ & $25.60 \%$ \\
\hline Total & $5.20 \%$ & $62.10 \%$ & $9.90 \%$ & $13.90 \%$ & $3.00 \%$ & $5.90 \%$ & $29.80 \%$ \\
\hline
\end{tabular}

Total number of observations is 59,950. The "self manage" category includes what various agencies refer to as "client can handle", "choose to self manage", or "self administer". "Not available" can be due to an incomplete session.

Table 3: Delivery Channel By Counselor Recommendation

\begin{tabular}{lcccc}
\hline & Face-to-face & Internet & Telephone & Overall \\
Counselor Recommendation & & & $5.20 \%$ \\
Self Manage/Client Can Handle & $6.60 \%$ & $3.30 \%$ & $5.10 \%$ & $62.10 \%$ \\
DMP recommended & $53.40 \%$ & $71.90 \%$ & $63.50 \%$ & $9.90 \%$ \\
Financial Counseling Only & $19.70 \%$ & $17.80 \%$ & $5.50 \%$ & $13.90 \%$ \\
Referal to Other Agency/Service & $10.70 \%$ & $2.60 \%$ & $16.60 \%$ & $3.00 \%$ \\
Referral to Legal Assistance & $4.90 \%$ & $2.10 \%$ & $2.50 \%$ & $5.90 \%$ \\
Not Available & $4.70 \%$ & $2.30 \%$ & $6.80 \%$ & $100.00 \%$ \\
& & & & $29.40 \%$ \\
Overall & $100.00 \%$ & $100.00 \%$ & $100.00 \%$ & $29.40 \%$ \\
Some DMP payments made & $32.90 \%$ & $21.50 \%$ & &
\end{tabular}

Percentages are for 59,950 sample of counseling agency clients. 


\section{Table 4: Determinants of Face-to-Face Counseling Channel; Alternative is Telephone (Probit Model)}

\begin{tabular}{|c|c|c|}
\hline & $\begin{array}{l}\text { Base specification with } \\
\text { only bureau variables }\end{array}$ & $\begin{array}{l}\text { Include additional } \\
\text { variables obtained } \\
\text { during counseling }\end{array}$ \\
\hline \multirow[t]{2}{*}{ Bankruptcy risk score (in 100s) } & -0.0047 & -0.0052 \\
\hline & -1.32 & -1.42 \\
\hline \multirow[t]{2}{*}{ Bankruptcy score in bottom $10 \%$ of combined sample } & 0.0004 & -0.0059 \\
\hline & -0.03 & -0.44 \\
\hline \multirow[t]{2}{*}{ Bankruptcy score in top $10 \%$ of combined sample } & -0.0103 & -0.0141 \\
\hline & -0.6 & -0.8 \\
\hline \multirow[t]{2}{*}{ Delinquency risk score (in 100s) } & $-0.0225 * * *$ & $-0.0139 *$ \\
\hline & -2.93 & -1.77 \\
\hline \multirow[t]{2}{*}{ Delinquency score in bottom $10 \%$ of combined sample } & $0.0256^{*}$ & 0.0182 \\
\hline & -1.83 & -1.28 \\
\hline \multirow[t]{2}{*}{ Delinquency score in top $10 \%$ of combined sample } & $0.0276^{*}$ & 0.0152 \\
\hline & -1.85 & -1 \\
\hline \multirow[t]{2}{*}{ Total number of trades with balance $>0$} & $0.0073 * * *$ & $0.0054 * * *$ \\
\hline & -4.92 & -3.55 \\
\hline \multirow[t]{2}{*}{ Total balance, non-mortgage trades (in 10,000 s) } & -0.0006 & 0.0019 \\
\hline & -0.55 & -1.62 \\
\hline \multirow[t]{2}{*}{ Total balance, mortgages (in 10,000s) } & 0.0003 & $0.0013 * *$ \\
\hline & -0.64 & -2.55 \\
\hline \multirow[t]{2}{*}{ Number of bankcard trades } & $-0.0055^{* * *}$ & $-0.0036 * * *$ \\
\hline & -6.21 & -3.92 \\
\hline \multirow[t]{2}{*}{ Proportion of bankcard trades with balance over $50 \%$ of limit } & $-0.0344 * *$ & -0.0095 \\
\hline & -2.46 & -0.66 \\
\hline \multirow[t]{2}{*}{ Number of non-inst trades over $50 \%$ of limit } & 0.0031 & 0.0021 \\
\hline & -1.48 & -0.94 \\
\hline \multirow[t]{2}{*}{ Number of trades 30 or more days past due in last $18 \mathrm{mths}$} & 0.0004 & -0.0004 \\
\hline & -0.25 & -0.27 \\
\hline \multirow[t]{2}{*}{ Number of currently past due balances } & 0.0018 & 0.0015 \\
\hline & -0.67 & -0.55 \\
\hline \multirow[t]{2}{*}{ Number of inquiries in last 6 months } & 0.0016 & 0.0014 \\
\hline & -1.16 & -0.97 \\
\hline \multirow[t]{2}{*}{ Highest retail credit limit (in $1,000 \mathrm{~s}$ ) } & -0.0008 & -0.0007 \\
\hline & -0.44 & -0.38 \\
\hline \multirow[t]{2}{*}{ Counseling Interview: Number of unsecured creditors } & & $0.0037 * * *$ \\
\hline & & -4.24 \\
\hline \multirow[t]{2}{*}{ Counseling interview: Total unsecured debt in $\$ 1,000$} & & $-0.0010 * * *$ \\
\hline & & -7.99 \\
\hline \multirow[t]{2}{*}{ Log of counselor experience (in months) } & & $0.2118 * * *$ \\
\hline & & -41.31 \\
\hline Number of Observations & 25997 & 25997 \\
\hline
\end{tabular}

Analysis restricted to five agencies that offer significant counseling services by phone and in person.

Coefficients indicate marginal effects; $* \mathrm{p}<.1 ; * * \mathrm{p}<.05 ; * * * \mathrm{p}<.01$ 
Table 5: Impact of Counseling Delivery Channel (Telephone versus In-Person) on Client Credit Outcomes, Two and Four Years After Counseling

Bankruptcy risk score (in 100s)

Bankruptcy score in bottom $10 \%$ of combined sample

Bankruptcy score in top $10 \%$ of combined sample

Delinquency risk score (in 100s)

Delinquency score in bottom $10 \%$ of combined sample

Delinquency score in top $10 \%$ of combined sample

Total number of trades with balance $>0$

Total balance, non-mortgage trades (in 10,000s)

Total balance, mortgages (in 10,000s)

Number of bankcard trades

Proportion of bankcard trades with balance over $50 \%$ of limit

Number of non-inst trades over $50 \%$ of limit

Number of trades 30 or more days past due in last 18 mths

Number of currently past due balances

\begin{tabular}{|c|c|c|}
\hline $\begin{array}{c}\text { Effect on } \\
\text { likelihood of } \\
\text { bankruptcy filing } \\
\text { over next four } \\
\text { years (Probit } \\
\text { model) }\end{array}$ & $\begin{array}{l}\text { Effect on Bureau } \\
\text { bankruptcy risk } \\
\text { score four years } \\
\text { later (OLS model) }\end{array}$ & $\begin{array}{l}\text { Effect on Burea } \\
\text { delinquency ris } \\
\text { score four years } \\
\text { later (OLS mode }\end{array}$ \\
\hline$-0.0193 * * *$ & $0.2457 * * *$ & $0.0397 * * *$ \\
\hline-6.44 & -17.82 & -7.16 \\
\hline 0.006 & -0.0538 & $0.0387 *$ \\
\hline-0.57 & -1.05 & -1.88 \\
\hline$-0.0382 * * *$ & 0.0459 & 0.0291 \\
\hline-2.69 & -0.69 & -1.09 \\
\hline $0.0381 * * *$ & $0.5828 * * *$ & $0.5667 * * *$ \\
\hline-5.96 & -19.54 & -47.24 \\
\hline 0.019 & 0.0308 & 0.0186 \\
\hline-1.59 & -0.57 & -0.85 \\
\hline-0.0156 & 0.0811 & -0.0257 \\
\hline-1.32 & -1.42 & -1.12 \\
\hline $0.0038 * * *$ & 0.0078 & 0.0035 \\
\hline-3.19 & -1.35 & -1.48 \\
\hline $0.0068 * * *$ & 0.0068 & $0.0115^{* * *}$ \\
\hline-7.77 & -1.55 & -6.51 \\
\hline$-0.0008 * *$ & $0.0082 * * *$ & $0.0024 * * *$ \\
\hline-2.03 & -4.14 & -2.99 \\
\hline-0.0004 & -0.0002 & $0.0197 * * *$ \\
\hline-0.5 & -0.05 & -14.29 \\
\hline $0.0362 * * *$ & $-0.2118 * * *$ & $0.0517 * *$ \\
\hline-3.06 & -3.9 & -2.37 \\
\hline $0.0057 * * *$ & $-0.1067 * * *$ & $-0.0217 * * *$ \\
\hline-3.35 & -12.75 & -6.43 \\
\hline$-0.0041 * * *$ & $0.0360 * * *$ & $0.0108 * * *$ \\
\hline-3.3 & -5.98 & -4.47 \\
\hline $0.0108 * * *$ & $-0.0297 * * *$ & $-0.0111 * * *$ \\
\hline-5.17 & -2.89 & -2.68 \\
\hline
\end{tabular}

$\begin{array}{ccc}\text { Effect on } & \text { Effect on Bureau } & \text { Effect on Bureau } \\ \text { likelihood of } & \text { bankruptcy risk } & \text { delinquency risk } \\ \text { bankruptcy filing } & \text { score two years } & \text { score two years } \\ \text { over next two } & \text { later(OLS model) } & \text { later (OLS model) } \\ \text { years (Probit } & & \\ \text { model) } & & \end{array}$

model)

$$
\begin{gathered}
-0.0226^{* * *} \\
-11.27 \\
-0.0149 * * \\
-2.31 \\
-0.1336 * * \\
-2.42
\end{gathered}
$$

$0.0364 * * *$

$$
-7.56
$$$$
0.0081
$$$$
-0.89
$$

$-0.1226 * * *$

$$
-3.16
$$

$0.0034 * * *$

$$
-3.41
$$

$0.0056 * * *$

$-7.85$

$-0.0004$

$$
-1.15
$$

$-0.0011 *$

\begin{tabular}{|c|c|}
\hline $0.3674 * * *$ & $0.0447 * * *$ \\
\hline-41.26 & -12.28 \\
\hline$-0.1221 * * *$ & 0.0146 \\
\hline-3.81 & -1.11 \\
\hline $1.4094 * * *$ & $0.3772 * * *$ \\
\hline-9.3 & -6.09 \\
\hline $0.4834 * * *$ & $0.6060 * * *$ \\
\hline-21.22 & -65.13 \\
\hline-0.0104 & -0.0115 \\
\hline-0.25 & -0.67 \\
\hline $0.5663 * * *$ & $0.2342 * * *$ \\
\hline-3.85 & -3.89 \\
\hline-0.0035 & 0.0017 \\
\hline-0.7 & -0.82 \\
\hline 0.0029 & $0.0118 * * *$ \\
\hline-0.78 & -7.65 \\
\hline $0.0061 * * *$ & $0.0038 * * *$ \\
\hline-3.54 & -5.4 \\
\hline$-0.0100 * * *$ & $0.0172 * * *$ \\
\hline-3.34 & -14.07 \\
\hline$-0.2089 * * *$ & 0.0204 \\
\hline-4.45 & -1.06 \\
\hline$-0.0712 * * *$ & $-0.0215 * * *$ \\
\hline-9.87 & -7.28 \\
\hline $0.0264 * * *$ & $0.0050 * *$ \\
\hline-5.09 & -2.35 \\
\hline-0.0049 & $-0.0170 * * *$ \\
\hline-0.55 & -4.69 \\
\hline
\end{tabular}

$-1.82$

$0.0214 * *$

$-2.13$

$0.0041 * * *$

$$
-2.91
$$

$-0.0024 * *$

$-2.23$

$0.0083 * * *$

$-4.74$ 


\begin{tabular}{|c|c|c|c|c|c|c|}
\hline & $\begin{array}{c}\text { Effect on } \\
\text { likelihood of } \\
\text { bankruptcy filing } \\
\text { over next four } \\
\text { years (Probit } \\
\text { model) }\end{array}$ & $\begin{array}{c}\text { Effect on Bureau } \\
\text { bankruptcy risk } \\
\text { score four years } \\
\text { later (OLS model) }\end{array}$ & $\begin{array}{c}\text { Effect on Bureau } \\
\text { delinquency risk } \\
\text { score four years } \\
\text { later (OLS model) }\end{array}$ & $\begin{array}{c}\text { Effect on } \\
\text { likelihood of } \\
\text { bankruptcy filing } \\
\text { over next two } \\
\text { years (Probit } \\
\text { model) }\end{array}$ & $\begin{array}{c}\text { Effect on Bureau } \\
\text { bankruptcy risk } \\
\text { score two years } \\
\text { later (OLS model) }\end{array}$ & $\begin{array}{c}\text { Effect on Bureau } \\
\text { delinquency risk } \\
\text { score two years } \\
\text { later (OLS model) }\end{array}$ \\
\hline \multirow[t]{2}{*}{ Number of inquiries in last 6 months } & $0.0105 * * *$ & $-0.0322 * * *$ & $-0.0082 * * *$ & $0.0059 * * *$ & $-0.0126 * * *$ & $-0.0091 * * *$ \\
\hline & -9.99 & -6.1 & -3.85 & -6.77 & -2.77 & -4.88 \\
\hline \multirow[t]{2}{*}{ Highest retail credit limit (in $1,000 \mathrm{~s}$ ) } & 0.0009 & $0.0238 * * *$ & $0.0176 * * *$ & 0.0009 & 0.008 & $0.0141 * * *$ \\
\hline & -0.62 & -3.43 & -6.3 & -0.73 & -1.33 & -5.77 \\
\hline \multirow[t]{2}{*}{ Counseling in person (alternative is telephone) } & $0.0229 * * *$ & $-0.0687 * *$ & -0.0071 & $0.0227 * * *$ & $-0.0425^{*}$ & 0.0012 \\
\hline & -3.64 & -2.33 & -0.6 & -4.24 & -1.67 & -0.12 \\
\hline \multirow[t]{2}{*}{ Counseling Interview: Number of unsecured creditors } & $0.0052 * * *$ & $-0.0267 * * *$ & $-0.0078 * * *$ & $0.0040 * * *$ & $-0.0229 * * *$ & $-0.0103 * * *$ \\
\hline & -7.64 & -7.96 & -5.75 & -7.33 & -8.06 & -8.84 \\
\hline \multirow[t]{2}{*}{ Counseling interview: Total unsecured debt in $\$ 1,000$} & $0.0002 * *$ & $0.0019 * * *$ & $0.0013 * * *$ & $0.0002 * *$ & 0.0001 & $0.0007 * * *$ \\
\hline & -2.4 & -4.03 & -7.07 & -2.07 & -0.15 & -4.15 \\
\hline \multirow[t]{2}{*}{ Log of counselor experience (in months) } & -0.0011 & -0.0062 & $-0.0116^{*}$ & -0.0027 & 0.0047 & -0.0067 \\
\hline & -0.33 & -0.4 & -1.88 & -0.95 & -0.36 & -1.23 \\
\hline \multirow[t]{2}{*}{ Evaluation: Self-manage/Client can handle } & $-0.0886 * * *$ & $0.2076^{* *}$ & $0.0768 * *$ & $-0.0669 * * *$ & $0.3375 * * *$ & $0.1177 * * *$ \\
\hline & -5.15 & -2.39 & -2.2 & -4.67 & -4.52 & -3.85 \\
\hline \multirow[t]{2}{*}{ Evaluation: DMP recommended by counselor } & -0.0042 & $-0.2308 * * *$ & $-0.0889 * * *$ & -0.0079 & $-0.1744 * * *$ & $-0.0676 * *$ \\
\hline & -0.26 & -3.06 & -2.93 & -0.58 & -2.69 & -2.55 \\
\hline \multirow[t]{2}{*}{ DMP payments started with recommendation } & $-0.0978 * * *$ & $0.3808 * * *$ & $0.1491 * * *$ & $-0.0778 * * *$ & $0.2041 * * *$ & $0.1615 * * *$ \\
\hline & -14.59 & -11.51 & -11.2 & -13.68 & -7.12 & -13.79 \\
\hline \multirow[t]{2}{*}{ DMP payments started without recommendation } & $-0.0904 * * *$ & $0.1682 *$ & 0.0326 & $-0.0739 * * *$ & 0.0585 & 0.0442 \\
\hline & -5.53 & -1.94 & -0.93 & -5.57 & -0.78 & -1.44 \\
\hline \multirow[t]{2}{*}{ Evaluation: Financial counseling only } & 0.006 & $-0.2481 * * *$ & $-0.0635^{*}$ & 0.0139 & $-0.1557 * *$ & -0.0452 \\
\hline & -0.33 & -2.96 & -1.88 & -0.91 & -2.17 & -1.54 \\
\hline \multirow[t]{2}{*}{ Evaluation: Referral to other agencies } & $0.0372 * *$ & $-0.2236 * * *$ & $-0.0548 *$ & $0.0327 * *$ & $-0.1483 * *$ & -0.0384 \\
\hline & -2.07 & -2.73 & -1.66 & -2.13 & -2.1 & -1.33 \\
\hline \multirow[t]{2}{*}{ Evaluation: Referral to legal assistance/advice } & $0.1950 * * *$ & $-0.7725 * * *$ & $-0.1171 * * *$ & $0.1752 * * *$ & $-0.6285^{* * *}$ & $-0.1499 * * *$ \\
\hline & -9.08 & -8.58 & -3.23 & -9.16 & -8.12 & -4.74 \\
\hline Number of Observations & 25997 & 25997 & 25997 & 25997 & 25997 & 25997 \\
\hline
\end{tabular}

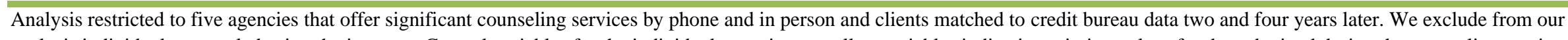

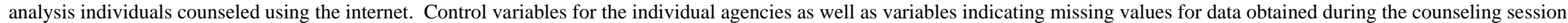
Coefficients for Probit indicate marginal effects; ${ }^{*} \mathrm{p}<.1 ; * * \mathrm{p}<.05 ; * * * \mathrm{p}<.01$ 
Table 6: Changes in Risk and Bankruptcy Scores, by Delivery Channel

For CCCS-Atlanta Clients Counseled in 2005 and in 2006

\begin{tabular}{|c|c|c|c|c|}
\hline \multirow{4}{*}{ CCCS Delivery Channel } & \multicolumn{2}{|c|}{ Risk Scores } & \multicolumn{2}{|c|}{ Bankruptcy Scores } \\
\hline & 2005 & 2006 & 2005 & 2006 \\
\hline & Appointment & Appintment & Appointment & Appointment \\
\hline & Year & Year & Year & Year \\
\hline \multicolumn{5}{|l|}{ Face To Face } \\
\hline Prior year score & 574.5 & 584.2 & 179 & 185 \\
\hline Score in year of appointment & 546.4 & 550.2 & 156 & 158.2 \\
\hline Following year score & 564.2 & 563.1 & 182 & 177.8 \\
\hline Number of observations & 1,524 & 1,161 & 1,542 & 1,180 \\
\hline Change in score from prior year & -28.1 & -34 & -23 & -26.8 \\
\hline Change in score in following year & 17.8 & 12.9 & 26 & 19.6 \\
\hline \multicolumn{5}{|l|}{ Internet } \\
\hline Prior year score & 607 & 607.6 & 182.9 & 184.1 \\
\hline Score in year of appointment & 568.7 & 555.4 & 151.4 & 141.5 \\
\hline Following year score & 578.9 & 570.2 & 178.2 & 170.2 \\
\hline Number of observations & 776 & 1,479 & 784 & 1,486 \\
\hline Change in score from prior year & -38.3 & -52.2 & -31.5 & -42.6 \\
\hline Change in score in following year & 10.2 & 14.8 & 26.8 & 28.7 \\
\hline \multicolumn{5}{|l|}{ Telephone } \\
\hline Prior year score & 574.3 & 586.5 & 171.9 & 181.9 \\
\hline Score in year of appointment & 543.8 & 546.4 & 150.8 & 153.6 \\
\hline Following year score & 565.4 & 562.8 & 179.1 & 173.4 \\
\hline Number of observations & 3,683 & 3,339 & 3,706 & 3,381 \\
\hline Change in score from prior year & -30.5 & -40.1 & -21.1 & -28.3 \\
\hline Change in score in following year & 21.6 & 16.4 & 28.3 & 19.8 \\
\hline \multicolumn{5}{|l|}{ Overall } \\
\hline Prior year score & 578.6 & 591.3 & 175.2 & 183 \\
\hline Score in year of appointment & 547.7 & 549.4 & 152.2 & 151.5 \\
\hline Following year score & 566.9 & 564.7 & 179.7 & 173.4 \\
\hline Number of observations & 5,983 & 5,979 & 6,032 & 6,047 \\
\hline Change in score from prior year & -30.9 & -41.9 & -23 & -31.5 \\
\hline Change in score in following year & 19.2 & 15.3 & 27.5 & 21.9 \\
\hline
\end{tabular}

Samples restricted to clients with face-to-face, telephone, or internet delivery channel who had matched risk scores 
Table 7: Demographic Differences by Delivery Channel For Clients in Budgeting Service Lines

For CCCS-Atlanta Clients Counseled in 2005 and in 2006

\begin{tabular}{|c|c|c|c|c|c|c|c|c|}
\hline Average age & $\begin{array}{l}\text { Percent } \\
\text { married }\end{array}$ & $\begin{array}{c}\text { Average net } \\
\text { income } \\
\text { (monthly) }\end{array}$ & $\begin{array}{c}\text { Percent } \\
\text { buying or } \\
\text { owning } \\
\text { home }\end{array}$ & $\begin{array}{l}\text { Average } \\
\text { total assets }\end{array}$ & $\begin{array}{c}\text { Percent with } \\
\text { no assets } \\
\text { reported }\end{array}$ & $\begin{array}{c}\text { Average } \\
\text { unsecurec } \\
\text { debt for } \\
\text { those } \\
\text { reporting } \\
\text { such debt }\end{array}$ & $\begin{array}{c}\text { Percent no } \\
\text { reporting } \\
\text { unsecurec } \\
\text { debt }\end{array}$ & $\begin{array}{c}\text { Percent } \\
\text { using } \\
\text { channel }\end{array}$ \\
\hline
\end{tabular}

Last Appointment in 2005

\begin{tabular}{|c|c|c|c|c|c|c|c|c|c|}
\hline Face To Face & 44.1 & $43.20 \%$ & $\$ 1,515$ & $33.20 \%$ & $\$ 36,695$ & $65.80 \%$ & $\$ 19,917$ & $49.00 \%$ & $25.50 \%$ \\
\hline Internet & 38 & $59.60 \%$ & $\$ 2,857$ & $34.70 \%$ & $\$ 106,665$ & $16.00 \%$ & $\$ 25,730$ & $1.00 \%$ & $13.00 \%$ \\
\hline Telephone & 43.5 & $47.60 \%$ & $\$ 1,836$ & $40.30 \%$ & $\$ 51,195$ & $54.30 \%$ & $\$ 18,755$ & $38.30 \%$ & $61.60 \%$ \\
\hline \multicolumn{10}{|c|}{ Last Appointment in 2006} \\
\hline Face To Face & 45.1 & $43.40 \%$ & $\$ 1,158$ & $24.20 \%$ & $\$ 33,577$ & $71.70 \%$ & $\$ 24,164$ & $47.30 \%$ & $19.40 \%$ \\
\hline Internet & 39.2 & $51.20 \%$ & $\$ 2,522$ & $50.80 \%$ & $\$ 108,433$ & $19.80 \%$ & $\$ 30,937$ & $2.80 \%$ & $24.70 \%$ \\
\hline Telephone & 44.6 & $47.90 \%$ & $\$ 1,429$ & $28.80 \%$ & $\$ 43,032$ & $61.90 \%$ & $\$ 23,120$ & $36.90 \%$ & $55.80 \%$ \\
\hline
\end{tabular}

Samples restricted to clients with face-to-face, telephone, or internet delivery channel who had matched risk scores for the appointment year and the years prior and subsequent to that year. For each level variable, statistics computed using non-missing values. 
Table 8: Factors Associated with Changes in Delinquency Risk Score From Prior Year and in Year Following Client's Last Appointment

\section{For CCCS-Atlanta Clients Counseled in 2006}

\begin{tabular}{|c|c|c|c|c|c|c|}
\hline & A & B & $\mathrm{C}$ & $\mathrm{D}$ & $\mathrm{E}$ & $\mathrm{F}$ \\
\hline & $\begin{array}{c}\text { Change in risk } \\
\text { score in year } \\
\text { prior to } 2006\end{array}$ & $\begin{array}{c}\text { Change in risk } \\
\text { score in year } \\
\text { following } 2006\end{array}$ & $\begin{array}{c}\text { Change in risk } \\
\text { score in year } \\
\text { following } 2006\end{array}$ & $\begin{array}{c}\text { Change in risk } \\
\text { score in year } \\
\text { following } 2006\end{array}$ & $\begin{array}{c}\text { Change in risk } \\
\text { score in year } \\
\text { following } 2006\end{array}$ & $\begin{array}{c}\text { Change in risk } \\
\text { score in year } \\
\text { following } 2006\end{array}$ \\
\hline \multirow[t]{2}{*}{ Internet delivery channel } & -10.558 & 1.903 & -0.44 & -1.49 & 0.91 & 0.192 \\
\hline & $(3.36)^{* * *}$ & -0.61 & -0.13 & -0.43 & -0.31 & -0.06 \\
\hline \multirow[t]{2}{*}{ Telephone delivery channel } & -1.46 & 3.399 & 3.078 & 2.792 & 0.096 & -0.003 \\
\hline & -0.59 & -1.25 & -1.13 & -1.03 & -0.04 & 0 \\
\hline \multirow[t]{2}{*}{ Result: debt management plan } & -11.772 & & 6.129 & 5.971 & -0.484 & -1.285 \\
\hline & $(3.95)^{* * *}$ & & $(1.89)^{*}$ & $(1.82)^{*}$ & -0.17 & -0.46 \\
\hline \multirow[t]{2}{*}{ Result: client can handle } & 13.386 & & -12.371 & -9.409 & 7.666 & 8.577 \\
\hline & $(1.70)^{*}$ & & -1.46 & -1.08 & -1.03 & -1.16 \\
\hline \multirow[t]{2}{*}{ Result: referred to legal agency } & -8.438 & & 8.562 & 7.852 & -2.212 & -2.786 \\
\hline & $(2.15)^{* *}$ & & $(2.02)^{* *}$ & $(1.82)^{*}$ & -0.6 & -0.75 \\
\hline \multirow[t]{2}{*}{ Result: referred to other agency } & 15.942 & & -60.024 & -59.223 & -33.633 & -32.549 \\
\hline & -0.49 & & $(1.69)^{*}$ & $(1.66)^{*}$ & -1.11 & -1.07 \\
\hline \multirow[t]{2}{*}{ Result: NA } & -0.918 & & -2.31 & 5.734 & -4.822 & -4.885 \\
\hline & -0.18 & & -0.92 & -1.04 & -1.02 & -1.03 \\
\hline \multirow[t]{2}{*}{ Client total assets } & -0.021 & & & -0.034 & -0.028 & -0.029 \\
\hline & $(1.99)^{* *}$ & & & $(2.88)^{* * *}$ & $(2.77)^{* * *}$ & $(2.92)^{* * *}$ \\
\hline \multirow[t]{2}{*}{ Client has no assets } & 5.62 & & & -3.278 & -5.144 & -4.762 \\
\hline & $(1.92)^{*}$ & & & -1.01 & $(1.86)^{*}$ & $(1.73)^{*}$ \\
\hline \multirow[t]{2}{*}{ Client total unsecured debt } & 0 & & & 0 & 0 & 0 \\
\hline & $(8.05)^{* * *}$ & & & -1.07 & -1.44 & -0.86 \\
\hline \multirow[t]{2}{*}{ Client unsecured debt level missing } & 3.263 & & & -7.493 & -3.939 & -3.717 \\
\hline & -0.91 & & & $(1.88)^{*}$ & -1.16 & -1.1 \\
\hline \multirow[t]{2}{*}{ Client net income } & 0.002 & & & -0.002 & 0 & 0.001 \\
\hline & $(2.52)^{* *}$ & & & $(2.25)^{* *}$ & -0.47 & -0.66 \\
\hline \multirow[t]{2}{*}{ Client married household } & 1.318 & & & -0.566 & 1.5 & 1.589 \\
\hline & -0.5 & & & -0.2 & -0.61 & -0.64 \\
\hline \multirow[t]{2}{*}{ Client age at time of interview } & -0.203 & & & -0.137 & 0.287 & 0.273 \\
\hline & $(2.14)^{* *}$ & & & -1.32 & $(3.21)^{* * *}$ & $(3.06)^{* * *}$ \\
\hline \multirow[t]{2}{*}{ Client age missing } & -14.863 & & & -12.177 & 19.167 & 18.156 \\
\hline & $(2.23)^{* *}$ & & & $(1.67)^{*}$ & $(3.05)^{* * *}$ & $(2.90)^{* * *}$ \\
\hline \multirow[t]{2}{*}{ Client owns or is buying a home } & -17.984 & & & 3.949 & 5.119 & 3.895 \\
\hline & $(6.13)^{* * *}$ & & & -1.22 & $(1.85)^{*}$ & -1.41 \\
\hline \multirow[t]{2}{*}{ Client's risk score, 2006} & 2.423 & & & & -1.791 & -1.626 \\
\hline & $(28.89)^{* * *}$ & & & & $(22.64)^{* * *}$ & $(19.30)^{* * *}$ \\
\hline \multirow[t]{2}{*}{ Client's score, 2006, squared } & -0.002 & & & & 0.001 & 0.001 \\
\hline & $(23.33)^{* * * *}$ & & & & $(17.78)^{* * *}$ & $(15.45)^{* * *}$ \\
\hline \multirow[t]{2}{*}{ Client's prior change in score, 2006} & & & & & & -0.068 \\
\hline & & & & & & $(5.58)^{* * *}$ \\
\hline \multirow[t]{2}{*}{ Constant } & -799.592 & 12.964 & 13.36 & 26.931 & 590.472 & 536.069 \\
\hline & $(34.25)^{* * *}$ & $(5.55)^{* * *}$ & $(4.89)^{* * *}$ & $(4.52)^{* * * *}$ & $(26.82)^{* * *}$ & $(22.31)^{* * *}$ \\
\hline Observations & 5979 & 5979 & 5979 & 5979 & 5979 & 5979 \\
\hline R-squared & 0.36 & 0 & 0 & 0.01 & 0.28 & 0.28 \\
\hline
\end{tabular}

Absolute value of $\mathrm{t}$ statistics in parentheses; $* \mathrm{p}<.1 ; * * \mathrm{p}<.05 ; * * * \mathrm{p}<. .01$

Samples restricted to clients with face-to-face, telephone, or internet delivery channel who had matched risk scores for the appointment year and the years prior and subsequent to that year. 
Table 9: Factors Associated with Changes in Bankruptcy Risk Score From Prior Year and in Year Following Client's Last Appointment

\section{For CCCS-Atlanta Clients Counseled in 2006}

\begin{tabular}{|c|c|c|c|c|c|c|}
\hline & A & B & $\mathrm{C}$ & $\mathrm{D}$ & $\mathrm{E}$ & $\mathrm{F}$ \\
\hline & $\begin{array}{c}\text { Change in risk } \\
\text { score in year } \\
\text { prior to } 2006\end{array}$ & $\begin{array}{c}\text { Change in risk } \\
\text { score in year } \\
\text { following } 2006\end{array}$ & $\begin{array}{c}\text { Change in risk } \\
\text { score in year } \\
\text { following } 2006\end{array}$ & $\begin{array}{c}\text { Change in risk } \\
\text { score in year } \\
\text { following } 2006\end{array}$ & $\begin{array}{c}\text { Change in risk } \\
\text { score in year } \\
\text { following } 2006\end{array}$ & $\begin{array}{c}\text { Change in risk } \\
\text { score in year } \\
\text { following } 2006\end{array}$ \\
\hline \multirow[t]{2}{*}{ Internet delivery channel } & -7.685 & 9.14 & 4.335 & 3.069 & 1.367 & 0.934 \\
\hline & $(2.90)^{* * *}$ & $(3.22)^{* *}$ & -1.43 & -0.98 & -0.47 & -0.32 \\
\hline \multirow[t]{2}{*}{ Telephone delivery channel } & 0.997 & 0.279 & 0.187 & -0.475 & -2.092 & -2.036 \\
\hline & -0.48 & -0.11 & -0.08 & -0.19 & -0.92 & -0.9 \\
\hline \multirow[t]{2}{*}{ Result: debt management plan } & -7.388 & & -6.038 & -5.656 & -7.653 & -8.07 \\
\hline & $(2.94)^{* * *}$ & & $(2.04)^{* *}$ & $(1.90)^{*}$ & $(2.78) * * *$ & $(2.94)^{* * * *}$ \\
\hline \multirow[t]{2}{*}{ Result: client can handle } & 6.666 & & -8.879 & -5.103 & 8.609 & 8.985 \\
\hline & -1.02 & & -1.18 & -0.66 & -1.21 & -1.26 \\
\hline \multirow[t]{2}{*}{ Result: referred to legal agency } & -0.156 & & 17.522 & 12.796 & 4.231 & 4.223 \\
\hline & -0.05 & & $(4.53)^{* * *}$ & $(3.27)^{* * *}$ & -1.17 & -1.17 \\
\hline \multirow[t]{2}{*}{ Result: referred to other agency } & -3.991 & & -23.039 & -19.752 & -16.351 & -16.576 \\
\hline & -0.15 & & -0.71 & -0.61 & -0.55 & -0.56 \\
\hline \multirow[t]{2}{*}{ Result: NA } & 1.759 & & -9.027 & 4.592 & -1.876 & -1.777 \\
\hline & -0.42 & & $(3.95)^{* * *}$ & -0.93 & -0.41 & -0.39 \\
\hline \multirow[t]{2}{*}{ Client total assets } & -0.027 & & & -0.041 & -0.035 & -0.037 \\
\hline & $(3.01)^{* * *}$ & & & $(3.85)^{* * *}$ & $(3.60) * * *$ & $(3.75)^{* * *}$ \\
\hline \multirow[t]{2}{*}{ Client has no assets } & -3.345 & & & -8.332 & -5.442 & -5.631 \\
\hline & -1.36 & & & $(2.86) * * *$ & $(2.02)^{* *}$ & $(2.09)^{* *}$ \\
\hline \multirow[t]{2}{*}{ Client total unsecured debt } & 0 & & & 0 & 0 & 0 \\
\hline & $(2.37)^{* *}$ & & & $(6.26)^{* * *}$ & $(3.68) * * *$ & $(3.56)^{* * *}$ \\
\hline \multirow[t]{2}{*}{ Client unsecured debt level missing } & 2.194 & & & -3.812 & -2.842 & -2.718 \\
\hline & -0.72 & & & -1.06 & -0.86 & -0.82 \\
\hline \multirow[t]{2}{*}{ Client net income } & 0.003 & & & -0.001 & -0.001 & -0.001 \\
\hline & $(3.77)^{* * *}$ & & & -1.34 & -1.09 & -0.89 \\
\hline \multirow[t]{2}{*}{ Client married household } & 8.49 & & & 2.53 & 2.039 & 2.517 \\
\hline & $(3.84)^{* * *}$ & & & -0.97 & -0.84 & -1.04 \\
\hline \multirow[t]{2}{*}{ Client age at time of interview } & 0.029 & & & 0.247 & 0.443 & 0.445 \\
\hline & -0.36 & & & $(2.63)^{* * *}$ & $(5.09)^{* * *}$ & $(5.11)^{* * *}$ \\
\hline \multirow[t]{2}{*}{ Client age missing } & 4.901 & & & 6.987 & 15.812 & 16.088 \\
\hline & -0.88 & & & -1.06 & $(2.60)^{* * *}$ & $(2.65)^{* * *}$ \\
\hline \multirow[t]{2}{*}{ Client owns or is buying a home } & -4.609 & & & 6.342 & -1.202 & -1.462 \\
\hline & $(1.85)^{*}$ & & & $(2.16)^{* *}$ & -0.44 & -0.54 \\
\hline \multirow[t]{2}{*}{ Client's bankruptcy score, 2006} & 0.773 & & & & -0.608 & -0.564 \\
\hline & $(25.67)^{* * *}$ & & & & $(18.46)^{* * *}$ & $(16.29)^{* * * *}$ \\
\hline \multirow[t]{2}{*}{ Client's score, 2006, squared } & -0.001 & & & & 0.001 & 0.001 \\
\hline & $(12.75)^{* * *}$ & & & & $(8.80)^{* * *}$ & $(8.05)^{* * *}$ \\
\hline \multirow[t]{2}{*}{ Client's prior change in score, 2006} & & & & & & -0.056 \\
\hline & & & & & & $(4.01)^{* * *}$ \\
\hline \multirow[t]{2}{*}{ Constant } & -119.548 & 19.535 & 23.533 & 13.91 & 79.133 & 72.393 \\
\hline & $(22.98) * * *$ & $(9.21)^{* *}$ & $(9.50)^{* * *}$ & $(2.58)^{* * *}$ & $(13.92) * * *$ & $(12.23) * * *$ \\
\hline Observations & 6047 & 6047 & 6047 & 6047 & 6047 & 6047 \\
\hline R-squared & 0.26 & 0 & 0.01 & 0.02 & 0.17 & 0.17 \\
\hline
\end{tabular}

Absolute value of $\mathrm{t}$ statistics in parentheses; * $\mathrm{p}<.1 ; * * \mathrm{p}<.05 ; * * * \mathrm{p}<. .01$

Samples restricted to clients with face-to-face, telephone, or internet delivery channel who had matched risk scores for the appointment year and the years prior and subsequent to that year. 
${ }^{1}$ The ten agencies that emerged from this process as participants in the study were Auriton Solutions (Roseville, MN), ClearPoint Financial Solutions, Inc. (Richmond, VA), Consumer Credit Counseling Service of Greater Atlanta, Inc. (Atlanta, GA), Consumer Credit Counseling Service of Los Angeles (Los Angeles, CA), Consumer Credit Counseling Service of Montana (Great Falls, MN), Consumer Credit Counseling Service of North Central Texas (McKinney, TX), InCharge Debt Solutions (Orlando, FL), LSS Financial Counseling Service (Duluth, MN), Novadebt (Freehold, NJ), and Money Management International (Houston, TX).

${ }^{2}$ Subsequent matching of the sample to the 2007 credit bureau archive reduced the sample to 51,739 due to missing credit reports or credit scores for some individuals.

${ }^{3}$ In Table 1, these were agencies A, C, D, G, and H.

${ }^{4}$ Additional specifications that also included geographic controls (namely, variables indicating the state of residence of the individual) did not alter these findings. 